\title{
Vojislav Trifunović ili Tomislav Lučić: tko će se lakše zaposliti u Zagrebu? Testiranje diskriminacije po nacionalnoj i dobnoj osnovi metodom prirodnog eksperimenta
}

\author{
Darja MASLIĆ SERŠIĆ \\ Odsjek za psihologiju Filozofskog fakulteta Sveučilišta u Zagrebu, Hrvatska \\ darja.maslic@ffzg.hr \\ Anton VUKELIĆ \\ Odsjek za sociologiju Filozofskog fakulteta Sveučilišta u Zagrebu, Hrvatska \\ avukelic@ffzg.hr
}

\begin{abstract}
Provedbom eksperimenta u prirodnim uvjetima ili metodom testiranja situacije autori su provjeravali jednakost prilika pojedinih skupina na tržištu rada. S pomoću writting test varijante metode ekvivalentnih parova ispitivali su postoji li pri zapošljavanju u Zagrebu diskriminacija osoba srpske nacionalnosti u usporedbi s njihovim hrvatskim parom, te četrdesetogodišnjaka u odnosu na dvadesetogodišnjake. Također, autore je zanimalo moderira li pojavu diskriminacije rod, razina obrazovanja i trenutačna potražnja (deficitarnost) za određenim profilom. Rezultati istraživanja temelje se na testiranju dvaju uzoraka od po 173 natječaja objavljena na internetskim portalima »MojPosao《 $\mathrm{i} » P o s a o . h r \ll$ te $\mathrm{u}$ dnevnim novinama. $\mathrm{Na}$ objavljene natječaje slane su prijave ekvivalentnih parova kandidata koji su se razlikovali ili po nacionalnom identitetu ili po dobi, a praćeni su ishodi tih prijava kao zavisne varijable. Tri moguće kategorije ishoda bile su: pozitivan odgovor poslodavca izražen kroz poziv kandidatu da pristupi daljnjem postupku selekcije, negativan odgovor ili odbijenica te, naposljetku, izostanak bilo kakve povratne informacije od poslodavca. Utvrđeno je postojanje diskriminacije i po nacionalnoj i po dobnoj osnovi već u prvom krugu odabira: kandidat čije ime i prezime asocira na srpsku nacionalnu pripadnost ima manje šanse za pozitivan ishod prijave od ekvivalentnog kandidata hrvatske nacionalne pripadnosti, a isto vrijedi i za četrdesetogodišnjake u odnosu na dvadesetogodišnjake. Razina obrazovanja i traženost određenog profila predviđaju ishod prijave za kandidate favoriziranih skupina, dok ishod natječaja za diskriminirane skupine posve ovisi o nekim drugim faktorima koji nisu zahvaćeni ovim istraživanjem. Osim spomenutim nalazima, rad se bavi i metodološkim pitanjima i daje preporuke za buduća slična istraživanja.
\end{abstract}

Ključne riječi: diskriminacija, prirodni eksperiment, metoda ekvivalentnih parova, dob, Hrvati, Srbi, zapošljavanje 


\section{Uvod}

Ime mi je Vojislav Trifunović, rođen u Zagrebu, nezaposlen. Poslao sam dvjestotinjak molbi za posao. Iako sam ispunjavao uvjete iz natječaja, na većinu nisam dobio odgovor ili su mi se samo zahvalili. Često se pitam na koliko natječaja su me izostavili samo zbog imena. Imam starijeg prijatelja Domagoja, četrdeset treća mu je na vratu. Ista situacija. On tvrdi da ga na većini oglasa, čim poslodavci vide njegove godine, odmah eliminiraju, kako se nema šanse zaposliti. Kaže da je gore njemu nego meni. Nisam siguran da je to točno. Inače je Domagoj u posljednje vrijeme nervozan $i$ šutljiv...

U društvima koja sebe legitimiraju kao demokratska, diskriminacija je osjetljiva tema. Kao suprotnost proklamiranoj ideologiji ravnopravnosti i ljudskih prava, ova pojava najčešće "pluta« u sivoj zoni društva, neuhvatljiva, skoro podjednako policijskim i pravnim institucijama koliko i društvenim istraživačima. Diskriminacija je ponašanje koje se po pravilu temelji na predrasudama prema osobama koje pripadaju nekoj društvenoj skupini. Ona predstavlja kršenje normi, najčešće i zakona; odvija se prikriveno od očiju javnosti, institucija $i$ istraživača. Obično su vidljive tek njezine posljedice u formi statističkih podataka o zastupljenosti pojedinih društvenih kategorija u različitim slojevima društva. No, podaci koji upućuju na neravnopravnu zastupljenost pojedinih skupina, ne moraju biti dokaz postojanja diskriminacije (Ofak, Starc i Šelo Šabić, 2006; Blank, Dabady i Citro, 2004). Diskriminacija je aktualno ponašanje prema pripadnicima druge skupine koje uključuje, uz mnoge druge oblike, ograničavanje pristupa resursima koji su dostupni našoj skupini. Za potrebe ove studije, definicija diskriminacije ograničit će se na ponašanja u kojima se član jedne skupine (nefavorizirana, najčešće označena kao manjina) tretira nepovoljnije nego članovi druge skupine (favorizirana, većina), a koji se nalaze u sličnoj situaciji, te stoga trpi nepoželjne ili negativne posljedice. Ova definicija diskriminacije koristi se u mnogim područjima društvenih znanosti te se odnosi na nejednak tretman osoba isključivo zbog njihove etničke, rodne ili druge pripadnosti. Spomenutu definiciju možemo podvesti pod diskriminaciju nejednakim tretmanom (engl. Disparate Treatment Discrimination), a kolidira $\mathrm{u}$ velikoj mjeri s kategorijom »namjerne diskriminacije« (Blank, Dabady i Citro, 2004: 39-54). Također, ovo je shvaćanje osnova i mnogih zakonskih definicija koje pokazuju da se zbog njihove pripadnosti određenoj skupini, različito tretiraju osobe u bitno sličnoj situaciji, a za što nema razumnog opravdanja, ili na ponašanja koja bez pravog razloga neke osobe ili skupine tretira nepovoljnije od drugih. Na primjeru zapošljavanja očito je kako je diskriminacija tek jedan od niza razloga zašto se pojedine osobe ili sku- 
pine teže zapošljavaju. ${ }^{1}$ Pristrano ponašanje poslodavca pri odabiru kandidata za posao koje rezultira različitim šansama odabira ljudi istih radnih, ali različitih demografskih karakteristika, može se, u skladu s prethodnom definicijom, označiti kao diskriminacija pri zapošljavanju, tj. kao različito tretiranje radnika zbog karakteristika koje nisu povezane s produktivnošću (Arrow, 1998).

\subsection{Metoda testiranja situacije korištenjem ekvivalentnih parova u istraživanju diskriminacije pri zapošljavanju}

U istraživanjima diskriminacije koristi se cijeli niz metoda i instrumenata. Spomenimo samo neke: laboratorijski eksperimenti koji uključuju igranje uloga, ispitivanje stavova/predrasuda poslodavaca o pojedinim manjinskim/etničkim skupinama, izravno promatranje i analiza procesa zapošljavanja, intervjui s poslodavcima o praksi zapošljavanja i diskriminacije, etnografske studije osobnog iskustva, intervjui i izvještaji o osobama koje su žrtve diskriminacije (Bovenkerk, 1992). Najčešće zamjerke pojedinim metodama vezane su uz sam način provedbe istraživanja koji se ne odvijaju u realnim uvjetima, što ograničava vanjsku valjanost rezultata te uz njihovu usredotočenost na pojedine slučajeve, a ne na sustavan uvid. Tako, primjerice, pri ispitivanju stavova ${ }^{2}$ poslodavci daju društveno poželjne odgovore, pa često nije opravdano na temelju iskazanih stavova zaključivati o njihovu ponašanju. Etnografske studije, ${ }^{3}$ koje su nezaobilazne $\mathrm{u}$ istraživanju tako delikatnih pojava poput »neuhvatljive« diskriminacije, zasigurno pružaju suptilne i iznijansirane spoznaje o tome kako se ona odvija i što doživljavaju pojedini akteri te ujedno nude šokantne priče koje vrlo lako emocionalno mobiliziraju javnost. Ipak, budući da se uglavnom temelje na kvalitativnom pristupu i analizi slučaja, one ne mogu odgovoriti na pitanje o razmjerima te pojave u društvu: je li to izoliran slučaj ili učestala pojava?

\footnotetext{
${ }^{1}$ Opsežna literatura pokazuje kako vjerojatnost zapošljavanja osobe na tržištu radne snage ovisi o kompleksnom nizu faktora te je nemoguće »optužiti« samo jedan od čimbenika kao uzrok nezaposlenosti pojedine osobe ili skupine. Izdvajamo: 1. potrebe tržišta rada; 2. osobni kapital nezaposlenih (različite socioekonomske karakteristike - dob, rod, profesija itd.; sposobnosti, vrijednosti, iskustvo i sl.); 3. društveni kapital nezaposlenih (veze i poznanstva); 4. ograničenja nezaposlenih; 5. razina motivacije za poslom kod nezaposlenih; 6. razina intenziteta traženja posla i način traženja; 7. diskriminacija (Galešić, Maslić Seršić i Šverko, 2004).

${ }^{2}$ Diskriminacija, nota bene, i jest čin, djelovanje, a ne stav (tada je riječ o diskriminacijskim stavovima).

${ }^{3}$ Npr. svojevremeno kod nas vrlo čitana knjiga Güntera Wallraffa Na samom dnu (1986), u kojoj autor, koji se prerušio u Turčina, živopisno opisuje svu nepravdu i diskriminaciju koja se događala »gastarbajterima« u tadašnjoj Zapadnoj Njemačkoj.
} 
Istraživanja diskriminacije metodom testiranja situacije (engl. situation testing) ili metodom ekvivalentnih parova pokušavaju izbjeći obje spomenute manjkavosti. Riječ je, zapravo, o provedbi eksperimenta u prirodnim uvjetima. Diskriminacija se propituje na način da se u realnoj situaciji koriste ekvivalentni parovi osoba koje su identične u svim karakteristikama osim u onoj za koju se pretpostavlja da može biti osnova diskriminacije. Najčešće su to etnička pripadnost, rod i dob, ali može se raditi i o drugim značajkama ljudi. Navedenom metodom opažamo stvarno ponašanje u realnim okolnostima, uz visok stupanj kontrole vanjskih faktora i osiguravanje unutarnje valjanosti istraživanja. Metoda ekvivalentnih parova primjenjuje se već četrdesetak godina u mnogim demokratskim zemljama, a provode je vladine i nevladine organizacije, ${ }^{4}$ instituti, pa čak, na vlastitu inicijativu, i velike korporacije (Bendick, 2007; Darity i Mason, 1998; Riach i Rich, 2002). ${ }^{5}$ Koliko nam je poznato, naše istraživanje prvo je takvo testiranje diskriminacije u Hrvatskoj.

Situacije u kojima se testira diskriminacija metodom ekvivalentnih parova mogu biti različite, a vrlo često je upravo riječ o zapošljavanju. ${ }^{6}$ Pritom, postoji nekoliko varijanti provedbe: (1) slanje isključivo pisanih aplikacija/molbi; (2) prijavljivanje na natječaje telefonom; (3) osobni odlazak i predaja pisane molbe; (4) osobni pristup te odlazak uvježbanih »glumaca« na intervjue s poslodavcima. Slanje pisanih aplikacija/molbi (engl. writting test method), koju smo koristili u našem istraživanju, često je korištena jer ne iziskuje velike financijske troškove i u relativno kratkom periodu može zahvatiti znatan broj natječaja, osobito danas kad se komunikacija odvija putem e-pošte. Dodatna je prednost relativno uspješna kontrola razlika među članovima ekvivalentnog para. Njezin je osnovni nedostatak u tome što se ograničava na prvu fazu postupka zapošljavanja - na prvi krug selekcije ili odabira osoba koje će poslodavci pozvati u daljnji postupak. Tako ostaje nepoznat konačan ishod selekcije. Zbog toga je metoda slanja pisanih aplikacija korisna za detektiranje same pojave diskriminacije, ali ne i za određivanje njezinih razmjera. Oni često mogu biti podcijenjeni jer se temelje samo na podacima o diskriminaciji u prvom selekcijskom krugu koji nam govori o tome hoće li neka osoba uopće biti razmatrana kao kandidat za

\footnotetext{
${ }^{4}$ Nevladine organizacije ponekad koriste metodu i kao valjani sudski dokaz u sporovima protiv korporacija u kojima je zamijećena diskriminacija.

${ }_{5}^{5}$ Motivi kompanijama su i ekonomske naravi. Naime, diskriminacija u konačnici znači da "prolaze« kandidati zbog rasnih, etničkih ili sličnih preferencija a ne profesionalnih kriterija te s aspekta produktivnosti zaposlit će se manje kvalitetni i efikasni kandidati.

${ }^{6}$ Metoda ekvivalentnih parova primjenjuje se i u području stanovanja - iznajmljivanja, usluga od dobivanja kredita, stipendija, zdravstvenih usluga, određivanja visine premija kod osiguranja i sl.
} 
ponuđeni posao. Kako se odabir kandidata gotovo redovito odvija u nekoliko koraka, pojava diskriminacije može se pojaviti u svakom od njih, sve do konačne odluke poslodavca o zapošljavanju neke osobe. ${ }^{7}$

Valjanost metode eksperimenta u prirodnim uvjetima ili testiranja situacije u istraživanjima diskriminacije ovisi o nekoliko ključnih metodoloških elemenata. Oni predstavljaju specifične izvore slabosti, pa valjanost dobivenih rezultata ovisi o uspješnosti njihove kontrole. Izdvojili smo osam, po nama ključnih, aspekata kontrole:

(1) Ekvivalentnost parova. Iako je ovaj problem ponajviše izražen u studijama s uvježbanim kandidatima koji odlaze na intervju, jer koliko god uvježbavali kandidate da daju identične odgovore i ostave isti dojam na poslodavca, nikada ne možemo biti sigurni u ekvivalentnost njihovih reakcija (Ward, 1969), problem ekvivalentnosti pojavljuje se i u pisanim aplikacijama/molbama. Kako životopisi ne smiju biti posve identični, istraživači mogu nehotice navesti podatak koji jednog kandidata favorizira nad drugim. Zato je podatke o zamišljenim kandidatima potrebno rotirati, a pisanje prijave ili životopisa razdvojiti od pridruživanja samog identiteta zamišljenog kandidata.

(2) Prepoznavanje, odnosno uočavanje pretpostavljene diskriminacijske razlike između parova. Naravno, ovaj problem nije izražen pri ispitivanju rodnih razlika ili kad se kandidati razlikuju po boji kože, posebice u testovima u kojima kandidati odlaze na intervju. Međutim, naglašavanje razlika nije jednostavno kod metode pisanih testova. Koliko god se istraživači trude naglasiti, primjerice, etničku pripadnost kandidata, ova differentia specifica može ostati nezamijećena od strane poslodavca pa tako u konačnici i ne utjecati na njegovu odluku o uključivanju kandidata u prvi krug selekcije.

(3) Medijacijske varijable. I brojni drugi faktori, osim diskriminacije, mogu utjecati na različiti tretman bitno istih kandidata, i to već u prvom krugu selekcije. Heckman i Siegelman (1993) upozoravaju na pretpostavku eksperimentatora o ravnomjernoj raspodjeli nezapaženih faktora produktivnosti između (favorizirane) većine i (diskriminirane) manjine koja ne mora biti takva, pa može utjecati na nejednak tretman kandidata. Istraživači nisu posve sigurni koje su to uopće moguće neprimijećene varijable koje poslodavci povezuju uz produktivnost kandidata te, na koncu, nismo sigurni otkrivaju li utvrđene razlike diskriminaciju. Primjerice, Neumark, Bank i Van Nort (1996) utvrdili su da su žene izložene diskriminaciji u skupim, ali ne u osrednjim ili jeftinim, restoranima, a Riach i Rich (2002)

\footnotetext{
${ }^{7}$ Izdvajaju se slučajevi kad se nefavorizirani kandidati pozivaju na intervjue, ali na samom intervjuu se događa svojevrsna diskriminacija: nezainteresirano ponašanje poslodavaca, kratka pitanja, ubrzani intervju, »slušaju, a ne čuju« i sl.
} 
nude otkriće da se žene suočavaju s diskriminacijom u zanimanjima poput kompjutorskog analitičara, ali ne u zanimanjima koji se bave računalnim programiranjem (?!).

(4) Zaključci o prirodi diskriminacije. S problemom medijacijskih varijabli povezani su i problemi vezani uz zaključke o prirodi diskriminacije. Valja naglasiti kako prirodni eksperimenti nisu dizajnirani na način koji bi omogućio čvrste zaključke o prirodi diskriminacije (Riach i Rich, 2002). Čak i kad metoda ekvivalentnih parova nudi rezultate koji statistički nedvojbeno govore o značajnim razlikama u tretiranju dviju skupina, ne može se zaključiti da je riječ o diskriminaciji temeljenoj na predrasudama i negativnim stavovima, a motivi poslodavca ostaju nerazjašnjeni. ${ }^{8}$

(5) Uzorak. Uzorak istraživanja su dostupni natječaji za radna mjesta. Međutim, istraživanja se redovito ograničavaju na natječaje koji ne zahtijevaju predaju određenih dokumenata ili radova u prvom krugu selekcije. Također, ovakva istraživanja ne obuhvaćaju one ponude poslodavaca koje nisu javne i otvorene. Kad govorimo o veličini uzorka, a ona ponajprije ovisi o planiranim statističkim analizama, većina autora se slaže da je uzorak od stotinjak parova (natječaja) dostatan, dok se za složenije statističke analize preporučuje (International Labour Organization, 2007) minimalno 170 parova, a njegova veličina ovisi i o broju neuspješnih pokušaja.

(6) Interpretacija natječaja »bez odgovora«. Jedan od ključnih kamena spoticanja primijenjene metodologije jest tretman onih slučajeva u kojima niti jedan od kandidata nije pozvan na intervju, odnosno niti jedan nije obaviješten o ishodu ili toku natječaja. Postavlja se pitanje je li to dokaz jednakog postupanja, to jest nediskriminacije (Bendick, 1996; Neumark, Bank i Van Nort, 1996), ili takve slučajeve moramo isključiti iz uzorka $\mathrm{s}$ argumentom da tu uopće nije ni provedena eksperimentalna situacija (pretpostavljamo da poslodavac molbe nije niti razmatrao). Drugim riječima, ne možemo znati razloge zbog kojih su oba kandidata isključena iz postupka zapošljavanja (Mclntosh i Smith, 1974). Darity i Mason (1998) priklanjaju se potonjem stajalištu tvrdeći da ako nepozivanje oba kandidata proglasimo primjerima nediskriminacije, provodimo prestrog test za diskriminaciju. ${ }^{9}$

\footnotetext{
${ }^{8}$ Dio poslodavaca ima određene predrasude prema pojedinim manjinama, a da ih i nisu u potpunosti svjesni. Također postoji i statistička diskriminacija ili profiliranje gdje se pripadnik pojedine skupine diskriminira samo zato što je vjerojatnost nepoželjnog ponašanja u njegovoj skupini veća, pa poslodavci ne žele riskirati. Dio poslodavaca uvažava dominantne stereotipe određene društvene sredine, opravdavajući to željama klijenata. Američka sudska praksa pokazuje da sva spomenuta »opravdanja« nisu dostatna ako se dokaže da poslodavac diskriminira zbog etničke ili druge pripadnosti.

${ }^{9}$ Znanstvena zajednica nije uvriježila niti jedan pristup, a može se zaključiti da je tu riječ o drukčijem tretiranju podataka, pa time i drugačijoj operacionalizaciji pojma diskriminacije.
} 
(7) Metode analize podataka i računanja »neto diskriminacije«. Ne postoji usuglašena metoda statističke analize dobivenih, u osnovi, jednostavnih podataka: broj pozitivnih, odnosno negativnih odgovora za (favoriziranu) većinu, i manjinu. Znatan broj radova koristi $\chi^{2}$ test, dok se u skladu s preporukama nekolicine autora (Bovenkerk, 1992; Heckman i Siegelman, 1993; McIntosh i Smith, 1974) i preporukom ILO-a (International Labour Organization, 2007) uvriježila statistička analiza nazvana neto diskriminacija (engl. total differential treatment). Izračunava se na način da se od broja slučajeva u kojima je samo pozvana favorizirana većina oduzme broj slučajeva u kojima je samo pozvana nefavorizirana manjina, a rezultat se podijeli s brojem valjanih testova. Diskriminacija može varirati $\mathrm{u}$ intervalu od $(-) 100 \%$, u potpunosti favorizirana manjina, do $(+) 100 \%$, potpuna diskriminacija manjine. Bendick (2007), na osnovi analize niza provedenih istraživanja, navodi kako prosječna neto diskriminacija za pojedine etničke skupine u Americi (crnci - bijelci; latino-skupina - anglo-skupina), iznosi oko $20 \%$, diskriminacija po rodu oko $25 \%$ (u korist muškaraca), po dobi oko $30 \%$ (u korist mlađih). Ovi postotci govore o razmjerima diskriminacije između pojedinih skupina.

(8) Specifični problemi pri testiranju dobne diskriminacije - problem radnog iskustva. Kod testiranja dobne diskriminacije postoji kontradiktornost između temeljnog zahtjeva metode da parovi budu ekvivalentni i neuvjerljivosti starijeg kandidata da »duljina« radnog iskustva bude identična kao kod mlađeg kandidata. Identično vrijedi i za psihofizičku kondiciju. Riach i Rich (2002) načelno preporučuju da umjesto toga da biografije kandidata podredimo zahtjevima metode (u smislu da se razlikuju samo u jednoj karakteristici - dobi), bolji put je da metodu podredimo starijem kandidatu. Bendick, Jackson i Romero (1997) te Bendick, Brown i Wall (1999) su navedeno razriješili navođenjem dijela radnog iskustva koje nije relevantno za traženo zanimanje. Dio istraživača (Riach i Rich, 2007) pokušava starijeg kandidata prikazati kao mentalno i fizički potentnog izmišljajući i navodeći njegove slobodne aktivnosti (biciklizam, skvoš, šah). Iskustvo dosadašnjih istraživanja dobne diskriminacije pokazuje da se takvo istraživanje ne može nekritički provesti na svim zanimanjima, te da tu valja pomno izdvojiti ona zanimanja za koja iskustvo i dob nisu presudni za uspješno obavljanje traženog posla. Očito je da se pri istraživanju dobne diskriminacije moramo pomiriti s činjenicom da istraživači nemaju pod kontrolom baš sve karakteristike u mjeri u kojoj bi željeli.

Navedene dvojbe i poteškoće koje »opterećuju« istraživanja metodom ekvivalentnih parova reflektirali su se i u istraživanju provedenom u Zagrebu, čiji prikaz slijedi. 


\section{Cilj i društveni kontekst provedenog istraživanja}

Predmet ovog istraživanja bila je diskriminacija pri zapošljavanju između dviju najbrojnijih nacionalnih skupina u hrvatskom društvu - Hrvata i Sr$\mathrm{ba}$, te u drugom dijelu istraživanja, osoba mlađe i srednje životne dobi. U uvjetima prirodnog eksperimenta, koristeći writting test varijantu metode ekvivalentnih parova, ispitivali smo postoji li pri zapošljavanju u Zagrebu diskriminacija osoba srpske nacionalnosti u usporedbi s njihovim hrvatskim parom, te osoba srednje životne dobi u odnosu na mlađe. Konkretno, dva su neposredna cilja provedenog istraživanja:

(1) ustanoviti provode li poslodavci već u prvom krugu selekcije diskriminaciju po nacionalnoj i dobnoj osnovi tako što neravnomjerno odabiru kandidate koji se u pisanoj aplikaciji jedino razlikuju u pretpostavljenoj pripadnosti hrvatskoj, odnosno srpskoj naciji ili u tome jesu li kandidati u četrdesetim ili dvadesetim godinama života;

(2) utvrditi moderira li pojavu diskriminacije rod, razina obrazovanja i potražnja za određenim profilom na tržištu radne snage.

Posredni cilj bio je uvesti metodu testiranja situacije ili prirodnog eksperimenta $\mathrm{u}$ istraživanja diskriminacije u Hrvatskoj te sistematizirati stečene spoznaje o primjeni ove metodologije.

$\mathrm{U}$ uvjetima relativno visoke stope nezaposlenosti u hrvatskom društvu, posao i zapošljavanje predstavljaju vrijedan resurs koji nije dostupan svim zainteresiranim pojedincima. Dakle, kako to nije marginalno područje društvenog života, moguće je očekivati da se pojedini odnosi i preferencije odražavaju u njemu. Istraživanja su pokazala da su demografske osobine nezaposlenih osoba, poput spola, dobi, obrazovanja ali i etničke odnosno nacionalne pripadnosti, značajan prediktor njihova ponovnog zapošljavanja koji je neovisan o samom intenzitetu traženja posla ili radnoj motivaciji neke osobe (Šverko i dr., 2008; Vinokur i Schul, 2002). Dakako, važnost demografskih karakteristika ljudi u prognozi njihove uspješnosti u zapošljavanju ne znači nužno dokaz diskriminacije. Kao što navode Hobfoll (1989) te Vinokur i Schul (2002), utjecaj demografskih osobina na uspješnost zapošljavanja može biti neizravan i posredovan medijacijskim varijablama kao što su dostupnost resursa potrebnih za uspješno traženje posla ili očuvanost psihofizičke dobrobiti tijekom nezaposlenosti. Predmet ovog istraživanja bio je specifičan utjecaj diskriminacije na različitu uspješnost $u$ zapošljavanju osoba većinske i manjinske nacionalne pripadnosti te mlađe i srednje životne dobi. U skladu s prethodnom definicijom, diskriminacijom smo smatrali ponašanje koje tretira nefavoriziranu skupinu (u našem slučaju osobe srpske nacionalnosti i starije) nepovoljnije od kandidata favorizirane skupine (u našem slučaju osobe hrvatske nacionalne pripadnosti i mlađe). 
Iako se istraživanje moglo usmjeriti na druge društvene skupine, opredijelili smo se za one nacionalne (i to isključivo za odnos Hrvati - Srbi) ${ }^{10}$ i dobne jer smo ih smatrali posebno relevantnima za suvremeno hrvatsko društvo.

Kad govorimo o odnosima Hrvata i Srba, treba napomenuti da je riječ o osnovnoj relaciji nacionalnih napetosti i sukoba početkom devedesetih godina prošlog stoljeća, $\mathrm{s}$ izraženom masovnom mobilizacijom hrvatskog $\mathrm{i}$ srpskog nacionalnog korpusa (Katunarić, 1991) i stvorenom netolerancijom (Sekulić, 2004). Jačanje dezintegracijskih procesa između Srba i Hrvata (Banovac i Boneta, 2006) i naglašavanje onih kulturnih markera koji ih razdvajaju, nerazmrsivo su povezani s emocionalnim nabojima i politizacijom etničnosti. Dakako, to je jedna strana argumentacije koja se temelji na događajima i procesima započetih prije dvadesetak godina i s različitim regionalnim intenzitetima. Druga se odnosi na poslijeratno redefiniranje odnosa između ovih dviju nacionalnih skupina. Procesima modernizacije, profiliranjem ekonomskih i materijalnih interesa, smirivanjem nacionalnih sukoba $\mathrm{i}$ napetosti te jačanjem integracije i tolerancije, mijenja se i slabi srpski i hrvatski nacionalni identitet. Empirijske verifikacije toga mogu se djelomično iščitati kroz istraživanja etničke distance koja pokazuju da ona slabi, ali i dalje postoji. Neovisno o činjenici da ona varira ovisno o regiji, urbanosti i istraživanoj društvenoj skupini, recentnija istraživanja (Banovac i Boneta, 2006; Malenica, 2007) pokazuju da otprilike trećina ispitanika ne bi prihvatila pripadnike srpske nacionalnosti kao suradnike na poslu.

Istraživanje diskriminacije po dobnoj osnovi prilikom zapošljavanja zanimljivo je zbog pojave dvaju suprotnih trendova u suvremenom društvu u kakvo se ubraja i Hrvatska. Prvi trend se odnosi na sve veći udio starijeg stanovništva, sve veću prosječnu dob ljudi te produženje prosječnog životnog vijeka i, s tim u vezi, usporen pad kvalitete života i psihofizičke dobrobiti ljudi u funkciji starenja. Rezultat je sve veći udio starijih ljudi u radno aktivnom stanovništvu te sve slabiji pad radnih kompetencija u funkciji dobi. Carone i Costello (2006) procjenjuju da će u Europi do 2050. godine većina (60\%) radne snage biti u dobi od 55-64 godina, dok brzi napredak tehnologija i općenita potreba za sve fleksibilnijom radnom snagom favorizira mladost (Posthuma i Campion, 2009). Drugim riječima, u društvima koja stare, istodobno se sve više cijene mladi lavovi, a sve manje stari vukovi. Spremnost na prilagodbu i sposobnost brzog učenja vrednije su radne osobine od iskustva i već stečenog znanja. Zato možemo pretpostaviti da se u skladu s uvriježenim dobnim stereotipima prema kojima se uz mladost vezuje fleksibilnost, brzina i sposobnost učenja, a uz starost neprilagodlji-

\footnotetext{
${ }^{10} \mathrm{Uz}$ Hrvate kao dominantnu skupinu mogu se pojaviti Romi, Slovenci, Bošnjaci i druge etničke, religijske, regionalne skupine, rodna diskriminacija itd.
} 
vost i nefleksibilnost, odvija i dobna diskriminacija prilikom zapošljavanja. U ovom slučaju manjina (mlađi) predstavlja favoriziranu (onu rjeđu i vredniju) skupinu u odnosu na većinu (osobe srednje dobi). Osim što je pojava ove diskriminacije u suprotnosti s proklamiranim normama, ona i izravno nepovoljno utječe na ekonomski rast jer zanemaruje radne potencijale većine ljudi i nije u skladu s dobnim trendovima društva.

Zagreb kao društveni kontekst provedenog istraživanja, u odnosu na druga područja Hrvatske, karakterizira visoka urbaniziranost, relativno niska stopa nezaposlenosti (anketna stopa nezaposlenosti iznosila je 9,4\% u vrijeme provedbe istraživanja) te pošteđenost od izravnih ratnih sukoba $i$ djelovanja tijekom devedesetih godina. Ova obilježja društvenog konteksta, u kojem je istraživanje provedeno, treba imati na umu prilikom interpretacije dobivenih rezultata, osobito pokušaja njihove generalizacije.

\section{Metoda}

Provedene su dvije neovisne sukcesivne studije koje su koristile istu metodologiju, ali su u fokusu imale različiti aspekt diskriminacije. Cilj prve studije bio je testirati postojanje diskriminacije po nacionalnoj osnovi, a druge, testirati postojanje diskriminacije po dobnoj osnovi.

\subsection{Formiranje ekvivalentnih parova}

Istraživanje se temeljilo na ranije opisanoj metodi prirodnog eksperimenta, testiranja situacije postupkom ekvivalentnih parova. Konkretno, na otvorene natječaje, slane su pisane aplikacije/molbe imaginarnih kandidata istovjetnih karakteristika s obzirom na tražene uvjete, ali implicitno pridruženih različitim nacionalnim, odnosno dobnim skupinama.

I. Ekvivalentni parovi kandidata hrvatske $i$ srpske nacionalne pripadnosti - Lučić vs. Trifunović. U prijavama nije bila eksplicitno napisana nacionalna pripadnost kandidata, ali su za kandidate odabrana imena koja se tradicionalno vezuju uz hrvatsku ili srpsku nacionalnu pripadnost. Odabrana imena bila su sljedeća: Tomislav Lučić i Martina Lučić za »hrvatske« kandidate i Vojislav Trifunović i Jovanka Trifunović za »srpske« kandidate. Bio je to i krucijalni dio korištene metode - određivanje identiteta imaginarnih nezaposlenih osoba pridružujući im tipična hrvatska i srpska imena. Pri određivanju imena koristili smo se telefonskim imenikom i odabrali smo ona prezimena i imena koja su najfrekventnija, a zadovoljavaju uvjet da asociraju ${ }^{11}$ na određenu nacionalnu pripad-

\footnotetext{
${ }^{11} \mathrm{U}$ ovoj fazi konstruiranja instrumenta dvojilo se asociraju li druga imena i prezimena (npr. Života, Višeslava, Bezbradica) po svojoj zvučnosti u većem stupnju na pretpostavljene nacionalne pripadnosti. Navedeno se može testirati.
} 
nost. S ciljem da poslodavci zaista uoče ime i prezime kandidata, ispisivali smo ih višestruko: na popratnom pismu deblje otisnuto ili napisano nešto većim fontom, na zaglavlju CV-a i kod potpisa na dnu CV-a, te su adrese e-pošte bile iskonstruirane iz imena i prezimena kandidata.

Tablica 1. Identiteti imaginarnih osoba - parovi muškog i ženskog roda za ispitivanje diskriminacije po nacionalnoj osnovi

\begin{tabular}{|l|l|l|}
\hline Ime $i$ prezime & Adresa & e-mail \\
\hline Tomislav Lučić & M. Ivanića 29, Zagreb & tomislav-lucic@net.hr \\
\hline Vojislav Trifunović & Štoosova 8, Zagreb & trifunovic.vojislav@gmail.com \\
\hline Martina Lučić & M. Ivanića 29, Zagreb & lucic.martina@gmail.com \\
\hline Jovanka Trifunović & Štoosova 8, Zagreb & jovanka.trifunovic@gmail.com \\
\hline
\end{tabular}

II. Ekvivalentni parovi kandidata mlađe i srednje životne dobi - četrdesetogodišnjak vs. dvadesetogodišnjak. U prijavama je ponekad eksplicitno napisana dob kandidata, ili je u biografskim podacima navedena godina rođenja - npr. 1982. ili 1962, a ponekad i kombinacija. Imena mlađih kandidata bila su Tomislav Lučić / Ankica Franić (mlađi kandidat, 20-25 godina), a onih srednje dobi Domagoj Franić / Martina Lučić (stariji kandidat, 40-45 godina).

Dakle, sveukupno su formirana četiri identiteta (dvije osobe ženskog i dvije muškog roda) za muški i ženski ekvivalentan par kandidata različite nacionalnosti te četiri identiteta kandidata različite životne dobi.

\subsection{Uzorak natječaja}

Istraživanje je provedeno na dva uzorka od po 173 natječaja za posao koje su objavili poslodavci iz Zagreba i uže okolice, u razdoblju od 1. listopada 2008. do 31. siječnja 2009. godine ${ }^{12}$ na specijaliziranim internetskim portalima www.moj-posao.net $\mathrm{i}$ www.posao.hr te $\mathrm{u}$ dnevnim novinama. ${ }^{13} \mathrm{U}$ prvom dijelu istraživanja testirana je diskriminacija po nacionalnoj osnovi (prva 173 natječaja), a u drugom dijelu je testirana diskriminacija po dobi (sljedeća 173 natječaja). Dakle, dobiveni rezultati temelje se na testiranju

12 Preliminarni rezultati ovog istraživanja predstavljeni su na znanstvenim skupovima Društvene promjene $i$ društvena struktura: Hrvatska 20 godina kasnije (Zagreb, 3-4. travnja 2009.) i 19. dani Zorana i Ramira Bujasa (Zagreb, 22-25. travnja 2009.). Valja napomenuti da je empirijski dio istraživanja trajao puno dulje jer su postojali slučajevi da su poslodavci odgovarali kandidatima i par mjeseci nakon završetka natječaja za posao.

${ }^{13}$ Natječaji koji su se pojavljivali u dnevnim novinama gotovo su po pravilu bili i na glavnim internetskim portalima ili su pripadali natječajima državnih institucija koji nisu mogli biti obuhvaćeni istraživanjima. 
ishoda 346 pojedinačnih ili 173 para ekvivalentnih pisanih prijava na javne natječaje za posao.

Iz istraživanja su bili izostavljeni: oglasi u kojima poslodavci zahtijevaju popratnu dokumentaciju, radove ili druge priloge; oglasi u kojima poslodavci zahtijevaju molbe i CV na stranom jeziku; oglasi u kojima poslodavci zahtijevaju da im se molba dostavi osobno; oglasi u kojima poslodavci zahtijevaju najavu kandidata putem telefona; oglasi koje su objavile specijalizirane agencije za zapošljavanje. Također, prijave su slane samo na natječaje u kojima se tražio samo jedan izvršitelj. Ako se poslodavac oglašavao više puta, molbe bi se slale samo jednom. Ako je poslodavac oglašavao više različitih radnih mjesta, izbor natječaja koji će biti predmet ispitivanja bio je slučajan. Na taj je način u oba dijela obrađeno ukupno 346 natječaja. Pritom, treba naglasiti kako istraživani uzorak natječaja nije reprezentativan zbog zahtjeva za dodatnom dokumentacijom (potvrdom o stručnoj spremi i državljanstvu), a posve su izostavljeni natječaji za posao u javnom sektoru.

Kako nije utvrđena razlika u strukturi objavljenih natječaja u dvama sukcesivnim razdobljima istraživanja, odnosno nije utvrđena razlika između dvaju testiranih uzoraka, iznosimo značajke ukupnog uzorka od 364 natječaja koliko ih je obrađeno u objema našim studijama. Prema traženoj razini obrazovanja, natječaji su u većini slučajeva nudili posao za koji je potrebna srednja stručna sprema (56\%), zatim viša i visoka (37\%), a tek je u $7 \%$ natječaja traženi uvjet bila završena osnovna škola. Većina je natječaja nudila poslove na kojima se pretežno zapošljavaju muškarci pa je $70 \%$ parova aplikacija bilo muškog roda, a $30 \%$ ženskog. Uzorak natječaja je pokrivao 76 različitih zanimanja od kojih osam čine dvije petine ukupnog broja. Tih osam najčešcih zanimanja su bili: prodavači (12\%), komercijalisti, rukovoditelji, knjigovođe, informatičari (po 5\%), inženjeri, programeri i tajnice (po 3\%). Ostatak od skoro sedamdesetak zanimanja čini $60 \%$ uzorka u kojima se većina pojavljuje tek jedanput. Gotovo su sva poduzeća bila privatna, u stranom ili domaćem vlasništvu (97\%), a većina natječaja, prema klasifikaciji s internetskih portala, dolazi iz sljedećih djelatnosti: trgovine, prodaje i marketinga (27\%), ekonomije, financija i osiguranja (15\%), strojarstva i elektrotehnike $(13 \%)$, računarstva i interneta $(9 \%)$ te administrativnih i građevinskih poslova (8\%). Natječaji su gotovo po pravilu nudili radni ugovor na neodređeno vrijeme, tj. stalno radno mjesto (94\%).

\subsection{Postupak prikupljanja podataka: slanje ekvivalentnih prijava i bilježenje odgovora}

$\mathrm{Na}$ objavljeni natječaj za posao slane su dvije elektroničke verzije sličnih, ne posve identičnih prijava imaginarnih osoba istog roda, ali imena koja upućuju na različitu nacionalnu pripadnost (u prvom dijelu istraži- 
vanja) ili godina rođenja koje odgovaraju osobi mlađe ili srednje životne dobi (u drugom dijelu istraživanja). Svaka se aplikacija sastojala od kratke prijave i životopisa. Životopisi kandidata bili bi uvijek formulirani tako da zadovoljavaju postavljene uvjete natječaja, a navedeni se podaci ne bi znatno razlikovali. Primjerice, pri istraživanju diskriminacije po nacionalnoj osnovi, jedan bi kandidat bio rođen 1972. a drugi 1973. godine, ili bi jedan imao devet, a drugi osam godina traženoga radnog iskustva. Kod kandidata različite životne dobi, osobita je pozornost posvećena traženom radnom iskustvu. Kao što je već spomenuto u uvodnom dijelu, istraživanja dobne diskriminacije donose inače dodatne specifične probleme upravo zbog kontradiktornosti između zahtjeva metode da parovi budu ekvivalentni i neuvjerljivošću starijeg kandidata da duljina radnog iskustva bude identična kao kod mlađeg kandidata. Mi smo se odlučili starijem kandidatu »pokloniti« više radnog iskustva i tako ga učiniti po toj osnovi privlačnijim. Tako bi u ovom provedenom istraživanju mlađi kandidat zadovoljavao minimalne uvjete u tom smislu, dok bi stariji kandidat imao više radnog iskustva od traženog minimuma. Time smo kandidate srednje životne dobi prikazali kao radno aktivne tijekom cijele dosadašnje karijere i onemogućili odbijanje starijeg kandidata uz racionalizaciju o neskladu njegove životne dobi i radnog iskustva. Osim toga, ta neujednačenost ekvivalentnog para u zadovoljavanju traženih uvjeta natječaja favorizirala je četrdesetogodišnjake za koje smo pretpostavljali da su diskriminirana skupina u odnosu na kandidate mlađe dobi.

Iako su natječaji gotovo redovito formulirani tako da su traženi $» m / \check{z}$ izvršitelji«, vodili smo računa da rod naših kandidata odgovara većinskoj rodnoj zastupljenosti u nekom zvanju. Za tipična ženska zanimanja (npr. sobarice, domaćice i sl.) prijavljivane su kandidatkinje, a za muška (npr. automehaničar, električar i sl.) kandidati. Oba/je su kandidata/kinje ispunjavali sve uvjete iz oglasa, ${ }^{14}$ imali identičan stupanj naobrazbe i ekvivalentno radno iskustvo. Prethodne kompanije u kojima su imaginarni kandidati/ kinje radili i škole koje su pohađali nisu bile izmišljene, nego stvarne, a ovisile su o konkretnim uvjetima natječaja. Molbe su pisane bez pravopisnih i tiskarskih pogrešaka, stilski ujednačeno i u skladu s pravilima i preporukama pisanja prijava za posao. Grafička obrada teksta se razlikovala u nebitnim elementima, kako bi se izbjegao dojam da ih je pisala ista osoba. Ukratko, poslane su prijave bile slične, ali ne identične, a razlike su

\footnotetext{
${ }^{14}$ Iznimno važan dio istraživanja sastojao se $\mathrm{u}$ »dobroj procjeni« formiranja CV-a kandidata. Treba poprilično opreza i mjere da se kandidate opiše na način da budu privlačni za poslodavca, a da opet se ne zapadne u zamku preobrazovanosti. Također je bilo vrlo osjetljivo odrediti obrazovne institucije ili poduzeća u kojima su kandidati dotad bili zaposleni. Potonje donosi i određene pravne probleme.
} 
u osnovi bile nebitne. Sve poslane prijave arhivirane su i dostupne zainteresiranim istraživačima.

Redoslijed slanja pisanih prijava pojedinih članova ekvivalentnog para bio je naizmjeničan. Eksperimentatori su najprije pomno iščitavali objavljene oglase, a potom bi pristupili pisanju molbi. Na svaki su oglas odaslane dvije prijave/molbe pripadnika/ce - hrvatske i srpske nacionalne pripadnosti (u prvom dijelu istraživanja) ili kandidata/kinje različite životne dobi (u drugom dijelu istraživanja). Svaka prijava sadržavala je sljedeće kontakte kandidata: poštansku adresu stanovanja, broj telefona, broj mobitela i adresu e-pošte. Eksperimentatori (jedna muška i jedna ženska osoba) pratili su i bilježili odgovore poslodavaca ${ }^{15}$ na svim navedenim kontaktima. Tako je svaka prijava klasificirana prema trima mogućim ishodima: pozvan/a, odbijena/a, bez odgovora poslodavca. Ako bi kandidat bio pozvan na razgovor, nakon nekog vremena, najčešće netom prije zakazanog sastanka ili nakon što bi i drugi kandidat također dobio poziv, razgovor bi se otkazivao uz ispriku o selidbi u drugo mjesto boravka zbog privatnih razloga.

\section{Rezultati}

\subsection{Testiranje postojanja diskriminacije po nacionalnoj osnovi: Vojislav Trifunović vs. Ivan Lučić $i$ Jovanka Trifunović vs. Martina Lučić}

Od ukupno 173 natječaja, koliko ih je činilo ispitivani uzorak, kod njih 103 (59,5\%) nijedan član ekvivalentnog para nije primio nikakav odgovor. Kod preostalih 70 natječaja, dakle njih više od $40 \%$ su oba ili barem jedan kandidat primili odgovor. U manjem broju slučajeva (njih 19 ili 5,5\% od ukupnog broja prijava) stigao je negativan odgovor. Istodobno, primljen je 101 (29,2\% od ukupnog broja poslanih prijava) pozitivan odgovor, odnosno poziv u daljnji postupak selekcije.

Dakle, možemo zaključiti kako su za većinu raspisanih natječaja naše prijave ostale bez ikakvog odgovora, iako su opisivale kandidate koji zadovoljavaju sve tražene uvjete natječaja. Nadalje, pristigli odgovori bili su u velikoj većini slučajeva pozitivni, a vrlo rijetko su primljeni negativni odgovori. U ovom dijelu analize, slučajeve bez odgovora okvalificirat ćemo kao negativne odgovore ili odbijenice, odnosno kao ravnopravno tretiranje naših kandidata tj. nediskriminaciju. ${ }^{16}$ Temeljna analiza prikupljenih poda-

\footnotetext{
${ }^{15}$ Iskustvo je pokazalo da su odgovori poslodavaca »klasičnom« poštom praktički zanemarivi te da u budućim istraživanjima kućne adrese mogu biti i izmišljene. Kako se znatan dio komunikacije odvija mobitelima, istraživači moraju praktički biti stalno dostupni.

${ }^{16}$ Kao što je u uvodnom dijelu rada spomenuto, ujedno je moguće da je tu riječ o »neuspješnim« eksperimentalnim situacijama, tj. da poslodavci uopće nisu razmatrali molbe.
} 
taka odnosi se na raspodjelu tih triju kategorija ishoda (pozitivan odgovor, negativan odgovor i bez odgovora na poslanu prijavu) na članove našeg ekvivalentnog para - Trifunović vs. Lučić.

Slika 1. Raspodjela ishoda prijava na članove ekvivalentnog para - srpske nacionalne pripadnosti (Trifunović) vs. hrvatske nacionalne pripadnosti (Lučić)

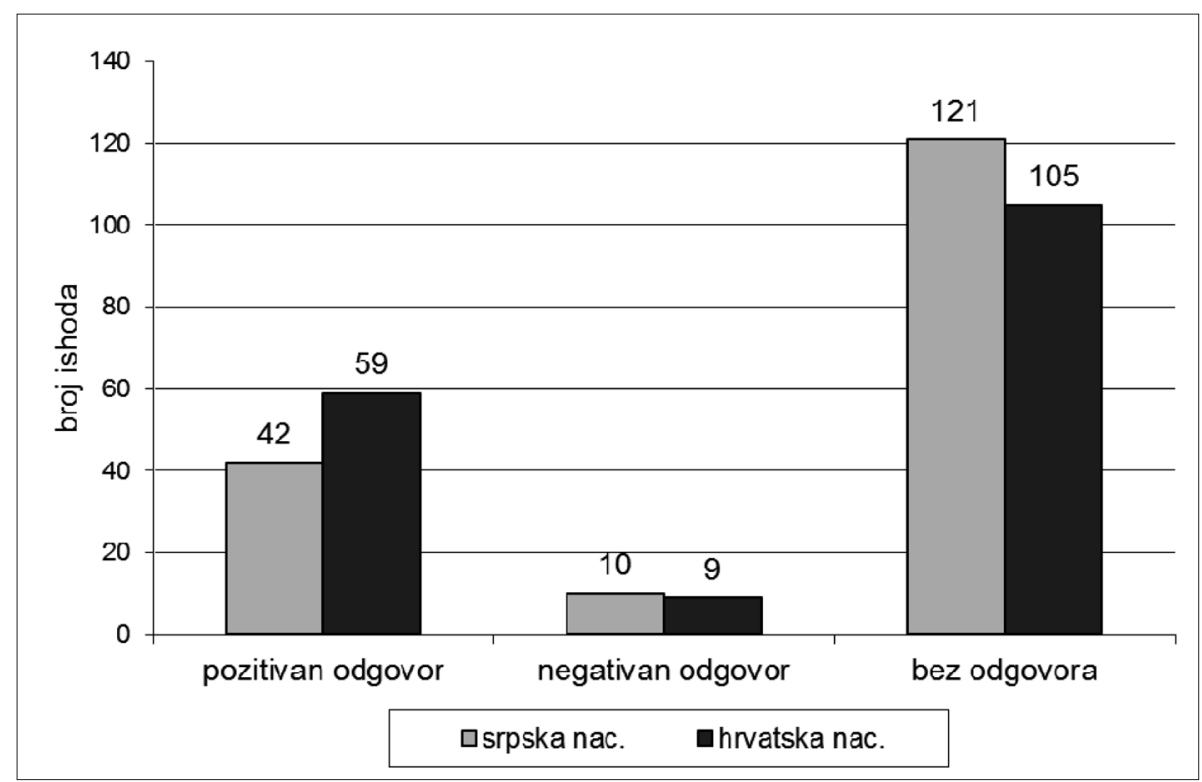

Tablica 2. Raspodjela ishoda prijava na članove ekvivalentnog para - srpske nacionalne pripadnosti (Trifunović) vs. hrvatske nacionalne pripadnosti (Lučić)

\begin{tabular}{|c|c|c|c|}
\hline & & \multicolumn{2}{|c|}{ Kandidat srpske nacionalne pripadnosti } \\
\hline & & pozvan & $\begin{array}{c}\text { negativan odgovor } \\
\text { ili bez odgovora }\end{array}$ \\
\hline \multirow{2}{*}{$\begin{array}{l}\text { Kandidat } \\
\text { hrvatske } \\
\text { nacionalne } \\
\text { pripadnosti }\end{array}$} & pozvan & 40 & 19 \\
\hline & $\begin{array}{l}\text { negativan odgovor } \\
\text { ili bez odgovora }\end{array}$ & 2 & 112 \\
\hline
\end{tabular}

Slika 1 prikazuje raspodjelu poslanih aplikacija s obzirom na njihov ishod te implicitni nacionalni identitet kandidata. Ako uzmemo u obzir sve prijave koje smo poslali, a ishode s negativnim odgovorom $\mathrm{i}$ one bez odgovora sažmemo u jednu kategoriju - prijave koje nisu rezultirale pozivom u sljedeći krug selekcije (Tablica 2) McNemarov $\chi^{2}$ test iznosi 13,76 
$(d f=1 ; p<0,01)$ i upućuje na statistički značajnu razliku u raspodjeli ovih ishoda u smjeru diskriminacije prijava srpske (Vojislava/Jovanke) u odnosu na one hrvatske nacionalne pripadnosti (Tomislava/Martine). Dakle, čak i u varijanti da sve slučajeve bez odgovora »proglasimo« ravnopravnim tretiranjem kandidata, distribucija odgovora poslodavaca nije slučajna s obzirom na nacionalnost kandidata i postoji diskriminacija nefavorizirane manjine.

\subsection{Testiranje postojanja diskriminacije po dobnoj osnovi: četrdesetogodišnjak vs. dvadesetogodišnjak}

I u ovom dijelu istraživanja, za većinu natječaja vezujemo izostanak bilo kakvog odgovora za oba kandidata (100 ili $57,8 \%$ od ukupnog broja natječaja), dok je kod 73 natječaja $(42,2 \%)$ pristigao odgovor na obje ili barem jednu prijavu. Ponovno je najmanje primljeno negativnih odgovora ili odbijenica (13 ili 3,8\% od ukupnog broja prijava), a pozitivnih odgovora bilo je 101 (29,2\% od ukupnog broja poslanih prijava). Time je potvrđena pouzdanost nalaza prvog dijela istraživanja o izostanku bilo kakve povratne informacije kao najvjerojatnijem ishodu prijave na natječaj za posao i za favoriziranu i za diskriminiranu skupinu.

Slika 2. Raspodjela ishoda prijava na članove ekvivalentnog para četrdesetogodišnjak vs. dvadesetogodišnjak

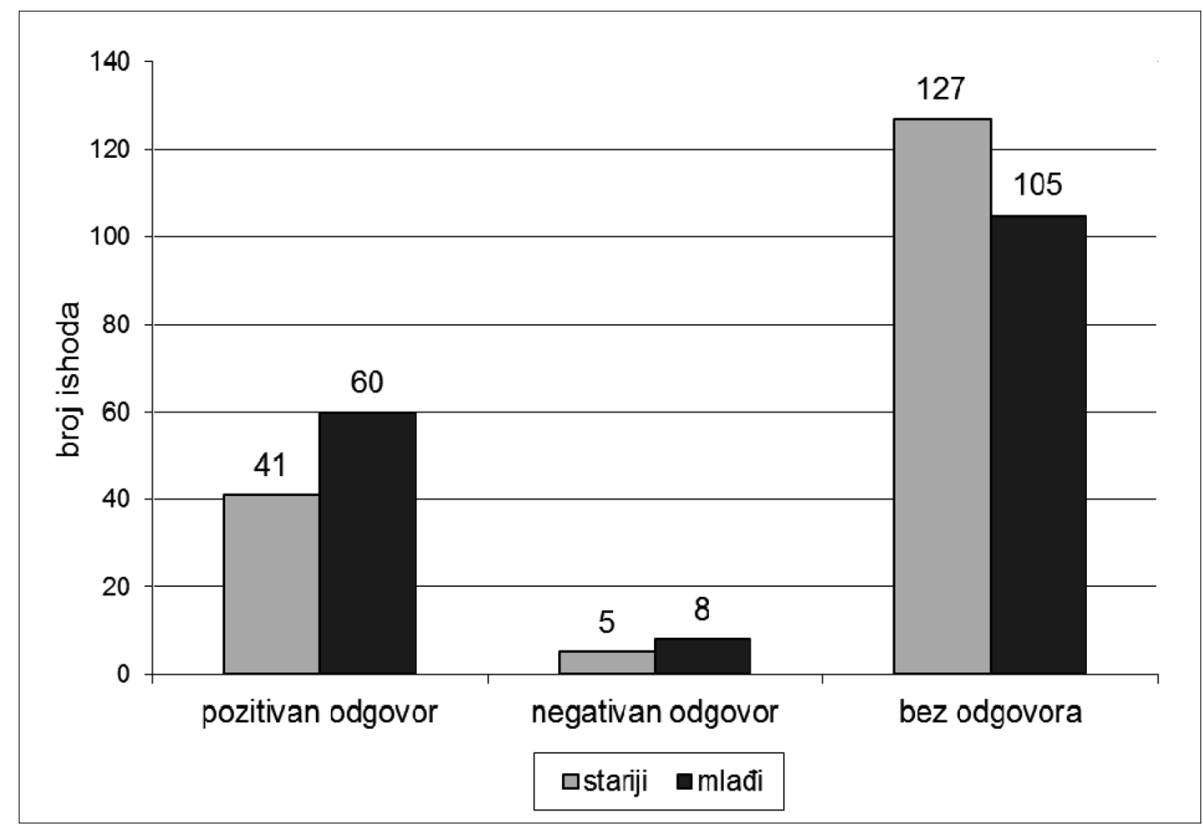


Tablica 3. Raspodjela ishoda prijava na članove ekvivalentnog para četrdesetogodišnjak vs. dvadesetogodišnjak

\begin{tabular}{|l|l|c|c|}
\hline & & \multicolumn{2}{|c|}{ Stariji kandidat } \\
\hline & & pozvan & $\begin{array}{c}\text { negativan odgovor } \\
\text { ili bez odgovora }\end{array}$ \\
\hline \multirow{2}{*}{$\begin{array}{l}\text { Mlađi } \\
\text { kandidat }\end{array}$} & pozvan & 36 & 24 \\
\cline { 2 - 4 } & $\begin{array}{l}\text { negativan odgovor } \\
\text { ili bez odgovora }\end{array}$ & 5 & 108 \\
\hline
\end{tabular}

Ponovno je središnji predmet interesa bila analiza razlika u raspodjeli pozitivnih i negativnih ishoda natječaja za prijave članova ekvivalentnog para - četrdesetogodišnjak vs. dvadesetogodišnjak. Slika 2 prikazuje raspodjelu triju kategorija ishoda (pozitivan odgovor, negativan odgovor, bez odgovora na poslanu prijavu) ovisno o dobi kandidata. Ponovno je primjetan trend diskriminacije četrdesetogodišnjaka kao pretpostavljene nefavorizirane skupine u odnosu na dvadesetogodišnjake. Ako, ponovno, dva nepovoljna ishoda (negativan odgovor i bez odgovora na prijavu) sažmemo u jednu kategoriju (Tablica 3), dobivamo statistički značajnu razliku u raspodjeli pozitivnih i negativnih ishoda prijave, ovisno o članu ekvivalentnog para - četrdesetogodišnjak vs. dvadesetogodišnjak. McNemarov $\chi^{2}$ test iznosi $12,45(d f=1 ; p<0,01)$ i upućuje na diskriminaciju kandidata srednje životne dobi u odnosu na mlađe kandidate. Napomenimo da je rezultat dobiven i unatoč činjenici da je stariji kandidat bio u prednosti i poželjniji jer imao i više godina radnog iskustva.

\subsection{Razmjeri utvrđene diskriminacije: neto diskriminacija po nacionalnoj i dobnoj osnovi}

U skladu s prethodno spomenutim preporukama, računali smo indeks neto diskriminacije [(broj natječaja na koji je pozvana samo favorizirana skupina - broj natječaja na koji je pozvana samo nefavorizirana skupina) / broj valjanih testova] koji nam govori o njezinim razmjerima te omogućuje usporedbu dobivenih nalaza s nalazima sličnih istraživanja u drugim zemljama. Pritom smo uzorak natječaja suzili na one kod kojih je barem za jednog kandidata pristigao odgovor poslodavca, smatrajući samo te situacije valjanim testovi$m a$ koje smo proveli. Drugim riječima, iz analiza su izbačeni oni natječaji kod kojih ni za jednog kandidata nije pristigao nikakav odgovor. Tako smo uzorak natječaja u prvom dijelu istraživanja, Trifunović vs. Lučić, sveli na 70 (broj valjanih testova), a u drugom dijelu istraživanja, četrdesetogodišnjak vs. dvadesetogodišnjak, na 73. Rezultati su prikazani u Tablici $4 .{ }^{17}$

\footnotetext{
${ }^{17}$ To je standardni format tablice prema McIntoshu i Smithu (1974).
} 
Tablica 4. Indeks neto diskriminacije za istraživanje diskriminacije po nacionalnoj (Trifunović vs. Lučić) i dobnoj (četrdesetogodišnjak vs. dvadesetogodišnjak) osnovi

\begin{tabular}{|c|c|c|c|c|c|c|c|c|c|c|}
\hline 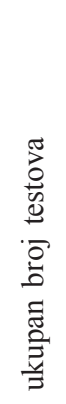 & 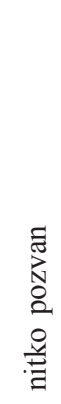 & 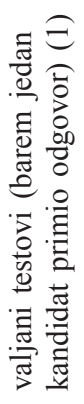 & & 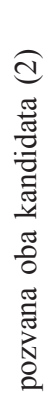 & 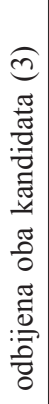 & 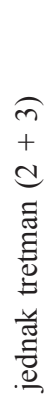 & 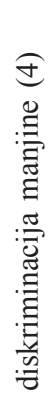 & 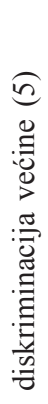 & 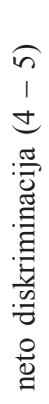 & 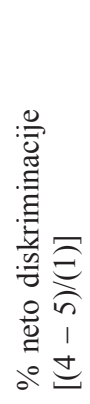 \\
\hline 173 & 103 & 70 & $\begin{array}{l}\text { Diskriminacija po } \\
\text { nacionalnoj osnovi } \\
\text { (Trifunović vs. Lučić) }\end{array}$ & 40 & 9 & 49 & 19 & 2 & 17 & $+24 \%$ \\
\hline 173 & 100 & 73 & $\begin{array}{l}\text { Diskriminacija po dobnoj } \\
\text { osnovi (četrdesetogodišnjak } \\
\text { vs. dvadesetogodišnjak) }\end{array}$ & 36 & 8 & 44 & 24 & 5 & 19 & $+26 \%$ \\
\hline
\end{tabular}

Podaci o neto diskriminaciji pokazuju da je u svakom četvrtom natječaju (od uzorka valjanih testova) kandidat Trifunović bio diskriminiran u odnosu na ekvivalentnog kandidata Lučića. To je također i slučaj sa svakim četvrtim natječajem kad govorimo o diskriminaciji četrdesetogodišnjeg kandidata u odnosu na njemu ekvivalentnog dvadesetogodišnjeg kandidata.

\subsection{Rod, razina obrazovanja i traženost profila kao moderatori pojave diskriminacije}

Poseban predmet našeg interesa bio je provjeriti moderiraju li pojavu diskriminacije neke druge demografske značajke naših kandidata, ali i broj kandidata $^{18}$ prijavljenih na određeni natječaj, tj. na raspisano radno mjesto. Ispitivane demografske značajke ograničili smo na rod i razinu obrazovanja, dok nam je podatak o broju kandidata na pojedinom natječaju zapravo bio nedostupan. Stoga smo ga, nažalost, reducirali na indirektne pokazatelje - indeks deficitarnosti pojedinog zanimanja, tj. općenitom potražnjom za nekim profilom na tržištu radne snage (operacionaliziran po zanimanjima na način: broj zaposlenih $\times 100 /$ broj novoprijavljenih $-\mathrm{u}$ određenom razdoblju). On nam aproksimativno govori o deficitarnosti ili suficitarnosti

\footnotetext{
${ }^{18}$ Nacrtom istraživanja smo pretpostavili da bi broj kandidata mogao imati presudan utjecaj na diskriminacijsko ponašanje poslodavaca odnosno na tijek eksperimenta.
} 
nekog zanimanja na tržištu radne snage. ${ }^{19}$ Veća vrijednost upućuje na veću potražnju za nekim profilom radne snage na tržištu rada u određenom razdoblju, pa je za očekivati da će se takvi kandidati suočavati s manjim selekcijskim omjerom te brže i lakše zapošljavati od kandidata čiji je profil vezan za suficitarna zanimanja u nekom razdoblju.

Analizu smo proveli na kumulativnom uzorku našeg istraživanja (346 natječaja i 692 poslane prijave), a kandidate smo podijelili u dvije skupine: diskriminiranu (pretpostavljena pripadnost srpskoj naciji i osobe srednje životne dobi) i nediskriminiranu (pretpostavljena pripadnost hrvatskoj naciji i mladi kandidati). Proveli smo dvije logističke regresijske analize na dvama odvojenim uzorcima prijava (diskriminirana skupina, $N=346$ ili nediskriminirana skupina, $N=346$ ). Kriterij je bio bivarijatan - pozitivan (pozivi u daljnji postupak) ili nepovoljan (negativan odgovor ili bez odgovora) ishod prijave. Rezultati logističkih regresijskih analiza pokazali su da je prediktivna snaga odabranih faktora $u$ predviđanju ishoda prijava na natječaj za posao moderirana statusom člana ekvivalentnog para. U nediskriminiranoj skupini (hrvatski ili mlađi član para) odabrani prediktori objašnjavaju značajan dio varijance ishoda natječaja (ukupna objašnjena varijanca iznosi $8 \% ; p<0,01)$, a pritom veću šansu za povoljnim ishodom

${ }^{19}$ Deficitarnost zanimanja, pojednostavljeno rečeno, označava situaciju na tržištu rada kad je potražnja za određenim zanimanjima veća nego ponuda djelatnika koji su kvalificirani, dostupni i voljni se zaposliti na radnom mjestu koje zahtijeva to zanimanje (Veneri, 1999). Na tržištu radne snage postoje različite situacije koje se ne mogu podvesti pod jednoznačni nazivnik, nerijetko odražavaju pojedine tendencije i nisu samo kvantitativni pokazatelji. Utoliko ne postoji suglasnost o pokazateljima koji bi vjerno opisali i poslužili kao određena empirijska mjera deficitarnosti za sva zanimanja. Zanimanja se bitno razlikuju u svojim tržišnim uvjetima, dijapazonu radnih mjesta koje pokrivaju, zahtjevima licenciranja i sl. Tek kombinacijom različitih pokazatelja praćenih tijekom duljeg perioda dobivamo vjerodostojniju sliku deficitarnosti (Cohen, 1995). Pokazatelji se najčešće temelje na nizu podataka o zapošljavanju, o nezaposlenosti i kretanju prosječnih plaća za određeno zanimanje ili skupinu zanimanja. Dodatni problem je što radno mjesto i zanimanje nisu sinonimi. Na HZZ-u ne postoji prihvaćena »formula « deficitarnosti te se uglavnom koriste podaci i njihovi međusobni odnosi o trenutnom broju nezaposlenih s pojedinim zanimanjem, brojem novoprijavljenih, brojem zaposlenih u određenom periodu i sl. Svjesni svih prethodno navedenih poteškoća naše istraživanje je kombiniralo podatke o broju zaposlenih $\times 100 /$ broj novoprijavljenih kao svojevrsnom indikatoru deficitarnosti. Uz sve manjkavosti i moguće opravdane primjedbe ovako konstruiranom indikatoru bili smo suočeni s još par problema. Prvo, zanimanja u klasifikaciji HZZ-a nisu u potpunosti istovjetna sa zanimanjima navedenim u natječajima. Drugo, ponekad se uz zanimanje zahtijevalo i posjedovanje svojevrsnih vještina $\mathrm{i}$ ispunjavanje određenih uvjeta. Treće, na pojedina radna mjesta iz natječaja, mogu konkurirati različita zanimanja s bitno drugačijim indeksima deficitarnosti što zbunjuje istraživače. Četvrto, s ciljem da izbjegnemo »sitne« brojeve nazivnika i brojnika našeg konstruiranog indeksa deficitarnosti, podaci o novoprijavljenim i zaposlenima su uzeti iz dužeg perioda, šire regije te podaci koji ponekad obuhvaćaju cijelu kategoriju zanimanja. U pripisivanju pojedinih indeksa deficitarnosti oslanjali smo se na arbitrarnost istraživača. 
imaju obrazovaniji kandidati te oni koji su aplicirali na radno mjesto za kojim vlada veća potražnja na tržištu rada. Istodobno, odabrani prediktori ne objašnjavaju značajan udio varijance ishoda natječaja za diskriminiranu skupinu (srpski i sredovječni član para). Ukupna objašnjena varijanca iznosi $2 \%(p<0,05)$. Rezultati su prikazani u Tablici 5. Isti je trend zabilježen na poduzorcima nediskriminirane i diskriminirane skupine. Tako odabrani prediktori objašnjavaju $6,4 \%(p=0,06)$ ishoda natječaja za hrvatski član para, odnosno samo $0,8 \%(p<0,05)$ varijance ishoda natječaja za srpski član para u istraživanju diskriminacije po nacionalnoj osnovi. Odabrani prediktori objašnjavaju $11 \%(p<0,01)$ varijance ishoda natječaja mladih kandidata (značajan samostalni prediktor je razina obrazovanja $-B=0,81$; $p=0,01)$, a samo $0,8 \%(p<0,05)$ varijance ishoda natječaja za sredovječne kandidate. Na temelju ovih rezultata možemo zaključiti da pretpostavljeni prediktori objašnjavaju ishode natječaja nediskriminiranih ili favoriziranih skupina, ali ne i diskriminiranih ili nefavoriziranih kandidata. U njihovom slučaju, odluka o tome hoće li poslodavac pozitivno odgovoriti na prijavu na natječaj za posao posve ovisi o nekim drugim faktorima.

Tablica 5. Rezultati logističkih regresijskih analiza za diskriminiranu i favoriziranu skupinu kandidata (kriterij: ishod poslane prijave povoljan ili nepovoljan)

\begin{tabular}{|c|c|c|c|c|c|c|}
\hline \multicolumn{7}{|c|}{$\begin{array}{l}\text { Favorizirana skupina }(N=346) \text {, ukupno objašnjene varijance kriterija } 8 \% \\
(p<0,01)\end{array}$} \\
\hline & $B$ & S.E. & $\begin{array}{l}\text { Waldov } \\
\text { F-test }\end{array}$ & $d f$ & $p$ & $\operatorname{Exp}(B)$ \\
\hline $\operatorname{rod}^{*}$ & 134 & ,302 & , 196 & 1 & ,658 & 1,143 \\
\hline razina obrazovanja** & 637 &, 179 & 12,604 & 1 &, 000 & 1,891 \\
\hline indeks deficitarnosti &,- 021 & 010 & 4,508 & 1 & ,034 & 979 \\
\hline \multicolumn{7}{|c|}{$\begin{array}{l}\text { Diskriminirana skupina }(N=346) \text {, ukupno objašnjene varijance kriterija } 2 \% \\
(p<0,05)\end{array}$} \\
\hline $\operatorname{rod}^{*}$ &, 024 & ,330 &, 005 & 1 & ,941 & 1,025 \\
\hline razina obrazovanja** & 310 &, 188 & 2,724 & 1 & ,099 & 1,364 \\
\hline indeks deficitarnosti &,- 001 & ,011 & ,013 & 1 & ,908 & ,994 \\
\hline
\end{tabular}

Napomena: * 1 = muškarci, $2=$ žene; $* * 1=$ osnovna šk., $2=$ srednja struč. sprema, $3=$ viša i visoka struč. sprema

\section{Rasprava}

Nalaze provedenoga prirodnog eksperimenta nužno je sagledati kroz tri pitanja: (1) postoji li diskriminacija, (2) u kojoj mjeri i (3) što to stvarno 
znači za diskriminiranu osobu ili skupinu? Potonje možemo formulirati vrlo konkretno: u kojem će dijelu natječaja osoba biti diskriminirana, tj. izostavljena iz daljnjega selekcijskog postupka?

Provedeni eksperiment pokazao je da već u prvom selekcijskom krugu na odluku utječu ime i dob kandidata, čime je potvrđeno postojanje diskriminacije na nacionalnoj i dobnoj osnovi. Indeks neto diskriminacije (koji se računa samo na valjanim testovima) u odnosu na osobu tipičnoga hrvatskog imena i prezimena iznosi $(+) 24 \%$. Ako iznos neto diskriminacije usporedimo s nalazima identičnih istraživanja među drugim etničkim skupinama, uočavamo da je tu riječ o prosječnoj stopi diskriminacije. S obzirom na ne tako davne etničke sukobe Hrvata i Srba, nije li bilo realno za očekivati daleko više stope diskriminacije? Očito da se »sile nacionalne netrpeljivosti« smiruju pod utjecajem integracijskih procesa. Naime, ipak je iza nas petnaestogodišnje razdoblje normalizacije i stabilizacije hrvatskog društva, dominiraju ekonomski procesi, nacionalistički ispadi se u znatnom dijelu javnosti osuđuju i sl. Istraživanje je provedeno samo u Zagrebu, kao najvećoj urbanoj sredini i na natječajima privatnih poduzeća. Što je od navedenih čimbenika integracije ovdje presudno i što je imalo pretežit utjecaj, ostaje otvorenim pitanjem. Isto vrijedi za pokušaj analize čimbenika diskriminacijskog ponašanja na razini natječaja. Tu je nužno obuhvatiti zanimanja, deficitarnost, broj pristiglih molbi, sociodemografske karakteristike poslodavca, te pokušati razotkriti motive poslodavaca. Je li nepovoljan položaj kandidata srpske nacionalne pripadnosti na tržištu rada uzrokovan negativnim stavovima poslodavaca prema toj skupini ili njihovim strahom da će ugroziti vlastiti status u društvu ili status tvrtke pred konkurencijom? Mi ne znamo ni jesu li u istoj situaciji osobe koje se u prijavama za posao izjašnjavaju kao pripadnici srpske nacije, ali taj nacionalni identitet nije prepoznatljiv iz njihova imena ili prezimena. Što se događa s osobama čije ime i prezime u manjem stupnju asocira na nacionalnu pripadnost ili nije jednoznačno? Tek bi buduća istraživanja provedena u drugim gradovima, na daleko većim uzorcima, u kojima bi se metoda ekvivalentnih parova primijenila i na neke druge skupine i zanimanja, mogla dati pouzdanije spoznaje o diskriminaciji u hrvatskom društvu.

Komparirajući naše istraživanje $\mathrm{s}$ drugim istraživanjima diskriminacije po etničkoj osnovi, postavilo se još jedno logično pitanje: kako to da u društvima koja u daleko većoj mjeri zadovoljavaju prethodno navedene kriterije integracije nailazimo na visoke stope neto diskriminacije (više od $40 \%$ pa čak do $80 \%$ ), a da nisu postojali recentni etnički sukobi poput onih na prostoru bivše Jugoslavije? Za ilustraciju: neto diskriminacija Marokanaca u Nizozemskoj, Belgiji i Španjolskoj iznosi 40-50\%, Vijetnamaca u Australiji 27\%, a Indijaca u Kanadi 40\%. Riach i Rich zaključuju da je jedan od ključnih čimbenika diskriminacije naglašena fizička različitost 
tako da dominantno bijele skupine poput Talijana ili Grka neće nikada dosegnuti one stope diskriminacije kao što je to slučaj s nebjelačkim skupinama (Riach i Rich, 2002: 503). Analogno tome, može se postaviti teza da je relativno niža stopa neto diskriminacije dobivena u našem istraživanju odraz relativne sličnosti Hrvata i Srba - kulturne, jezične pa i sličnosti na razini fizičkog izgleda. U pokušajima detektiranja varijabli koje mogu utjecati na diskriminaciju pri zapošljavanju, valja uvijek imati na umu da odnos poslodavca prema jednoj etničkoj skupini obuhvaća odnos prema cijelom nizu karakteristika koje tu skupinu obilježavaju. Također ostaje otvorenim pitanje o tendenciji stope diskriminacije u budućnosti - hoće li se stabilizirati na ovoj razini i je li to njezin minimum?

Što je stvarna posljedica iznosa neto diskriminacije od 25\%? Pokazuje li nam taj podatak da je u stvarnosti kandidat s tipično srpskim imenom i prezimenom na svakom četvrtom natječaju diskriminiran u odnosu na ekvivalentnog kandidata s tipičnim hrvatskim imenom i prezimenom? I točno i netočno! Kamen spoticanja su upravo natječaji u kojima nismo dobili niti jedan odgovor i način kako da ih interpretiramo. Ako su to primjeri nediskriminacije kao slučajevi podjednakog tretmana kandidata, onda su otprilike u jednoj desetini natječaja pripadnici srpske nacionalnosti diskriminirani u odnosu na njihove hrvatske parove. Ako su to neuspjeli eksperimentalni slučajevi, onda zaista pojava diskriminacije postoji u jednoj četvrtini natječaja. Dakle, može se zaključiti na temelju ovakvoga zagrebačkog uzorka da diskriminacija zbog »neprikladnog « imena kandidata sigurno varira unutar intervala od jedne desetine do jedne četvrtine natječaja. ${ }^{20}$ Navedeni interval tek djelomično korespondira s odgovorima poslodavaca (v. Franc i dr., 2010). ${ }^{21}$

Naši rezultati o diskriminaciji kandidata različite dobi također potvrđuju postojanje diskriminacije na tržištu radne snage u Zagrebu. Ovaj put, indeks neto diskriminacije iznosi $(+) 26 \%$, što znači da je kandidat sred-

\footnotetext{
${ }^{20}$ Dvije napomene: prvo, za precizniju procjenu unutar navedenog intervala potrebno je drukčije koncipirati istraživanje, istraživanje koje će moći u većoj mjeri procijeniti razloge nepozivanja i neodgovaranja kandidatima; drugo, spomenuti iznos neto diskriminacije ostaje kao valjana referentna točka za komparaciju s drugim istraživanjima diskriminacije jer su provedena u osnovi identičnom metodologijom i statistički izračunata na istovjetan način.

${ }^{21}$ Naime, u spomenutom istraživanju (Franc i dr., 2010) 5,6\% poslodavaca odgovara da u njihovom poduzeću vjerojatno postoji diskriminacija po etničkoj osnovi, 7,7\% tvrdi da je etnička pripadnost važan kriterij pri zapošljavanju u njihovom poduzeću; a desetina poslodavca smatra da nije dobro da osoba druge etničke pripadnosti komunicira s klijentima, odnosno $15 \%$ ih je na tu tvrdnju neodlučno. Podaci dobiveni u ovom radu i netom citiranom istraživanju nisu jednostavno usporedivi zbog niza razloga. Njihovo navođenje prelazi okvire rada.
} 
nje životne dobi u istoj situaciji kao netom spomenuti pripadnik srpske nacionalnosti, tj. na svakom četvrtom natječaju je diskriminiran u odnosu na mlađeg kandidata. Iako je razlika u dobi naših dvaju članova ekvivalentnog para iznosila (prvih) dvadesetak godina radno aktivnog razdoblja života te $\mathrm{u}$ istraživanju nisu konfrontirani kandidati na početku i na kraju radne karijere, zabilježeni razmjeri diskriminacije su veliki, tim više što je stariji kandidat imao prednost $\mathrm{u}$ radnom iskustvu. Možemo samo pretpostaviti razmjer nepoželjnosti starijih kandidata koji nisu kroz život sakupili dovoljno godina radnog staža. Iako nismo ispitivali prirodu diskriminacije, odnosno motivaciju poslodavaca za različit tretman ekvivalentnih kandidata, s priličnom sigurnošću možemo pretpostaviti prisutnost uvjerenja o smanjenoj radnoj produktivnosti starijih osoba. Dobiveni rezultati potvrđuju izjave kako nezaposlenih tako i poslodavaca u Hrvatskoj da je dob glavni kriterij pri zapošljavanju, odnosno temelj diskriminacije (v. Franc i dr., 2010). Ovakvi stavovi i vjerovanja poslodavaca kose se sa suvremenim spoznajama psihologije rada koje je vjerojatno najbolje opisao Warr (1994: 309): »Rezultati više od stotinu objavljenih istraživanja pokazuju da ne postoji značajna razlika u radnoj učinkovitosti između starijih i mladih radnika«. Kao što smo u uvodnom dijelu i istaknuli, zbog produljenja životnog i radnog vijeka ljudi te sve većeg udjela osoba srednje i starije životne dobi u populaciji, ova je diskriminacija također relevantna, a puno je rjeđe ispitivana od diskriminacije na nacionalnoj/rasnoj osnovi (v. Riach i Rich, 2006). U jednom od rijetkih eksperimentalnih istraživanja diskriminacije na dobnoj osnovi, Riach i Rich (2006) na uzorku natječaja za konobare u Francuskoj utvrđuju jedan od najviših indeksa diskriminacije ikad zabilježenih u istraživanjima diskriminacije. Konfrontirajući dvadesetsedmogodišnjake i četrdesetsedmogodišnjake utvrđuju indeks neto diskriminacije od više od 58\%. Zanimljivo je da je veći indeks zabilježen u glavnom gradu, Parizu, nego u ostatku zemlje, te za nemanualne poslove $u$ odnosu na manualne. Razlika istog smjera između glavnog grada i ostatka zemlje dobivena je i u komparabilnoj studiji provedenoj u Velikoj Britaniji (Riach i Rich, 2007). Bez obzira na to što smo svom starijem kandidatu poklonili iskustvo, dobna je diskriminacija izraženija nego ona po nacionalnoj osnovi. Očito da stereotipi i predrasude prema starijim osobama na koje nailazimo u mnogim društvima postoje i u hrvatskom društvu. Kad govorimo o tržištu rada, onda je osobito vrijedno istaknuti institucionalni oblik ove diskriminacije koji podrazumijeva zakone, pravila i praksu koja diskriminira starije u odnosu na mlađe radnike. Mogli bismo reći da se u ove oblike ubraja i obveza odlaska u mirovinu u određenoj životnoj dobi, bez obzira na radnu sposobnost ili motivaciju, ili, u Hrvatskoj često prisutno rješenje, problema viška radnika »prisilnim« umirovljenjem osoba koje su stekle prve dobne uvjete za odlazak u mirovinu. Ako znamo koliki udio 
takvih »mladih « umirovljenika Hrvatska ima, onda nas ne treba čuditi niti zabilježena diskriminacija pri zapošljavanju osoba u četrdesetim godinama $\mathrm{u}$ odnosu na one $\mathrm{u}$ dvadesetim.

Možemo zaključiti da su naši rezultati očekivani te da potvrđuju unutarnju valjanost provedenog istraživanja. Drugo je pitanje koliko je ovolika diskriminacija štetna i na društvenoj i na individualnoj razini. Arrow (1998) upozorava na povezanost diskriminacije sa smanjenom ekonomskom učinkovitošću društva. Na individualnoj razini, ova pojava, osim što krši temeljna ljudska prava te povećava stresnost $i$ inače zahtjevnog procesa traženja posla (Maslić Seršić i Šavor, 2011), čini neke radno sposobne i motivirane osobe izloženijima pojavi produljene nezaposlenosti, a time i smanjenoj dobrobiti i društvenoj isključenosti (Paul i Moser, 2009; Šverko, Galić i Maslić Seršić, 2006). To se osobito odnosi na osobe srednje životne dobi, što je i bio predmet naše eksperimentalne manipulacije u istraživanju diskriminacije po dobnoj osnovi, kod kojih bilježimo najveći pad dobrobiti u funkciji nezaposlenosti (Maslić Seršić, Šverko i Galešić, 2005; Warr, 2007; Jackson i Warr, 1984).

Raspravu o dobivenim rezultatima zaključit ćemo novim pitanjima koja se ovdje nameću: Što je s osobama koje imaju više od jedne značajke koja može biti osnova za diskriminaciju? Što je s osobama koji nemaju konkurentne ili prestižne radne karakteristike, a pritom imaju neku značajku koja predstavlja temelj za diskriminaciju? Kolike su šanse da Jovanka Trifunović dobije posao u Zagrebu, ako je riječ o već dulje vrijeme nezaposlenoj ženi srednje životne dobi koja ne posjeduje neke posebno tražene kvalifikacije ili radno iskustvo? Nadamo se da ova pitanja mogu biti poticaj za daljnja istraživanja, ali i društvene intervencije. U tom kontekstu, osobito je važno razmatrati kumulativne učinke diskriminacije po različitim osnovama (v. Blank, Dabady i Citro, 2004: 68).

Na kraju, recimo nešto i o metodološkim ograničenjima, ali i potencijalima korištene metode prirodnog eksperimenta s ekvivalentnim parovima. Smatramo kako je korištena metoda osigurala zadovoljavajuću unutarnju valjanost dobivenih rezultata jer je omogućila: (1) otkrivanje društveno neprihvatljivih oblika ponašanja poslodavaca koji često ostaju prikriveni društveno poželjnim ponašanjem; (2) dobivanje rezultata sukladnih rezultatima istraživanja diskriminaciji u drugim zemljama. Kad govorimo o vanjskoj valjanosti naših nalaza, u većoj smo mjeri kritični. Smatramo kako mogućnost generalizacije rezultata ograničavaju i specifičnost područja istraživanja u smislu mjesta njegove provedbe (Zagreb) i specifičnost područja ponašanja (odluke poslodavaca u prvom krugu selekcije kandidata za posao). Iako smo dokazali postojanje diskriminacije po nacionalnoj osnovi, mi i dalje možemo samo pretpostavljati događa li se ona i drugim nacionalnim skupinama u Hrvatskoj i u kolikom razmjeru. Isto vrijedi i za druge dobne i rodne skupine i druga 
područja ljudskog djelovanja. Koliko su žene diskriminirane pri zapošljavanju kod zanimanja rezerviranih za muškarce? Iako mogućnost neravnopravnog tretmana ekvivalentnih kandidata raste svakim krugom odabira, to se $\mathrm{u}$ realnim uvjetima ne mora događati. U sljedećim krugovima selekcije, koji uglavnom uključuju i osobni kontakt s kandidatom, možda druge osobine kandidata zasjenjuju njihove demografske karakteristike. To ne znači da opet nije riječ o nekoj diskriminaciji, ali ovaj puta po drugoj osnovi. Primjerice, u često citiranoj studiji Hamermesh i Biddle (1994) dokazano je da ljudi dobrog izgleda predstavljaju favoriziranu skupinu u svijetu rada, te da su učinci ove diskriminacije izraženiji kod muškaraca nego kod žena.

Kao i inozemna istraživanja, i naše je istraživanje bilo ograničeno na uzorak poslodavaca u privatnom poslovnom sektoru. Iako se smatra kako su upravo ovi poslodavci vođeni isključivo poslovnim interesima pri zapošljavanju pa zanemaruju druge, za posao irelevantne značajke kandidata, to uvjerenje ne mora biti točno. Dakle, osim što bi buduća istraživanja trebalo provesti u različitim regijama Hrvatske te u različitim »nišama« tržišta rada, bilo bi dobro detaljnije istražiti i motive poslodavaca. Korištena metoda eksperimenta nudi neke mogućnosti i u ovom području. Na primjer, moguće je kod obaju članova ekvivalentnog para prezentirati istu značajku koja može biti temelj za diskriminaciju, ali na različit način (izravan ili neizravan, lako ili teže prepoznatljiv), a moguće je i manipulirati različitim brojem favoriziranih ili diskriminiranih značajki.

Naše je istraživanje uspjelo dokazati pojavu diskriminacije na nacionalnoj i dobnoj osnovi prilikom odabira kandidata za posao u Zagrebu. Rezultat je to korištenja metode testiranja situacije čija je suština provedba eksperimenta u prirodnim uvjetima, a predmet interesa nisu stavovi i uvjerenja, nego stvarno ponašanje poslodavaca.

\section{LITERATURA}

Arrow, Kenneth J. (1998). »What Has Economics to Say about Racial Discrimination?«, Journal of Economic Perspectives, 12 (2): 91-100.

Banovac, Boris i Boneta, Željko (2006). »Etnička distanca i socijalna (dez)integracija lokalnih zajednica«, Revija za sociologiju, 37 (1-2): 21-46.

Bendick, Marc, Jr. (1996). Discrimination against raciallethnic minorities in access to employment in the United States: Empirical findings from situation testing (International Migration Papers 12). Geneva: International Labour Office.

Bendick, Marc, Jr. (2007). »Situation Testing for Employment Discrimination in the United States of America«, Horizons stratégiques, 3 (5): 17-39.

Bendick, Marc, Jr., Brown, Lauren E. i Wall, Kennington (1999). »No Foot in the Door: An Experimental Study of Employment Discrimination Against Older Workers«, Journal of Aging and Social Policy, 10 (4): 5-23. doi:10.1300/ J031v10n04_02 
Bendick, Marc, Jr., Jackson, Charles W. i Romero, J. Horacio (1997). »Employment Discrimination Against Older Workers: An Experimental Study of Hiring Practices«, Journal of Aging and Social Policy, 8 (4): 25-46. doi:10.1300/ J031v08n04_03

Blank, Rebecca M., Dabady, Marilyn i Citro, Constance F. (ur.) (2004). Measuring Racial Discrimination: Panel on Methods for Assessing Discrimination. Washington, D.C.: The Nacional Academies Press.

Bovenkerk, Frank (1992). Testing Discrimination in Natural Experiments: A Manual for International Comparative Research on Discrimination on the Grounds of »Race» and Ethnic Origin. Geneva: ILO.

Carone, Giuseppe i Costello, Declan (2006). „Can Europe Afford to Grow Old?«, Finance and Development, 43 (3), http://www.imf.org/external/pubs/ft/ fandd/2006/09/carone.htm.

Cohen, Malcolm S. (1995). Labor Shortages as America Approaches the Twentyfirst Century. Ann Arbor: University of Michigan Press.

Darity, William A., Jr. i Mason, Patrick L. (1998). »Evidence on Discrimination in Employment: Codes of Color, Codes of Gender«, Journal of Economic Perspectives, 12 (2): 63-90.

Franc, Renata, Ferić, Ivana, Rihtar, Stanko i Maričić, Jelena (2010). Raširenost $i$ obilježja diskriminacije na hrvatskom tržištu rada: izvješće na temelju ankete među nezaposlenim osobama $i$ ankete među poslodavcima. Zagreb: Institut društvenih znanosti Ivo Pilar. http://www.hzz.hr/docslike/Izvjestaj_SECLM. pdf (27. 07. 2010.).

Galešić, Mirta, Maslić Seršić, Darja i Šverko, Branimir (ur.) (2004). Psihološki aspekti nezaposlenosti. Zagreb: Filozofski fakultet.

Hamermesh, Daniel S. i Biddle, Jeff E. (1994). »Beauty and the Labor Market«, American Economic Review, 84 (5): 1174-1194.

Heckman, James J. i Siegelman, Peter (1993). »The Urban Institute Audit Studies: Their Methods and Findings«, u: Michael Fix i Raymond J. Struyk (ur). Clear and Convincing Evidence: Measurement of Discrimination in America. Washington, D.C.: Urban Institute Press, str. 187-258.

Hobfoll, Stevan E. (1989). „Conservation of resources: A new attempt at conceptualizing stress«, American Psychologist, 44 (3): 513-524. doi:10.1037/0003066X.44.3.513

International Labour Organization (2007). »Situation Testing« - Discrimination in Access to Employment: Based on ILO Methodology. www.ilo.org.

Jackson, Paul R. i Warr, Peter B. (1984). »Unemployment and psychological illhealth: The moderating role of duration and age «, Psychological Medicine, 14 (3): 605-614. doi:10.1017/S003329170001521X

Katunarić, Vjeran (1991). »Dimenzije etničke distance u Hrvatskoj«, u: Mladen Lazić (ur.). Položaj naroda i međunacionalni odnosi u Hrvatskoj: sociologijski $i$ demografski aspekti. Zagreb: Institut za društvena istraživanja Sveučilišta u Zagrebu, str. 129-139.

Malenica, Zoran (2007). Ogledi o hrvatskom društvu: prilog sociologiji hrvatskog društva. Zagreb: Golden marketing - Tehnička knjiga. 
Maslić Seršić, Darja i Šavor, Majda (2011). »Konstrukcija upitnika suočavanja s gubitkom posla«, Društvena istraživanja, 20 (2): 495-515. doi:10.5559/di.20.2.11

Maslić Seršić, Darja, Šverko, Branimir i Galešić, Mirta (2005). »Unemployment and dimensions of subjective health: Exploring moderating effects of age $\ll$, Studia Psychologica, 47 (3): 221-234.

McIntosh, Neil i Smith, David J. (1974). The Extent of Racial Discrimination (Broadsheet, 547). London: Political and Economic Planning.

Neumark, David, Bank, Roy J. i Van Nort, Kyle D. (1996). »Sex Discrimination in Restaurant Hiring: An Audit Study«, Quarterly Journal of Economics, 111 (3): 915-941.

Ofak, Lana, Starc, Nenad i Šelo Šabić, Senada (ur.) (2006). Siromaštvo, nezaposlenost i socijalna isključenost. Zagreb: Program Ujedinjenih naroda za razvoj (UNDP) u Hrvatskoj. http://www.undp.hr/upload/file/104/52134/FILENAME/ Siromastvo, $\% 20$ nezaposlenost $\% 20 \mathrm{i} \% 20$ socijalna $\% 20$ iskljucenost.pdf.

Paul, Karsten I. i Moser, Klaus (2009). »Unemployment impairs mental health: Meta-analyses«, Journal of Vocational Behavior, 74 (3): 264-282. doi:10.1016/j. jvb.2009.01.001

Posthuma, Richard A. i Campion, Michael A. (2009). »Age Stereotypes in the Workplace: Common Stereotypes, Moderators, and Future Research Directions«, Journal of Management, 35 (1): 158-188. doi:10.1177/0149206308318617

Riach, P[eter] A. i Rich, J[udith] (2002). »Field experiments in discrimination in the market place«, The Economic Journal, 112: F480-F518.

Riach, Peter A. i Rich, Judith (2006). »An Experimental Investigation of Age Discrimination in the French Labour Market«, IZA Discussion Paper No. 2522, Bonn, Institute for the Study of Labor (IZA).

Riach, Peter A. i Rich, Judith (2007). »An Experimental Investigation of Age Discrimination in the English Labor Market«, IZA Discussion Paper No. 3029, Bonn, Institute for the Study of Labor (IZA).

Sekulić, Duško i dr. (2004). Sukobi i tolerancija: o društvenoj uvjetovanosti nacionalizma i demokracija. Zagreb: Naklada Jesenski i Turk i Hrvatsko sociološko društvo.

Šverko, Branimir, Galić, Zvonimir i Maslić Seršić, Darja (2006). »Nezaposlenost i socijalna isključenost: longitudinalna studija«, Revija za socijalnu politiku, 13 (1): 1-14. doi:10.3935/rsp.v13i1.417

Šverko, Branimir, Galić, Zvonimir, Maslić Seršić, Darja i Galešić, Mirta (2008). »Unemployed people in search of a job: Reconsidering the role of search behavior«, Journal of Vocational Behavior, 72 (3): 415-428. doi:10.1016/j. jvb.2007.11.006

Veneri, Carolyn M. (1999). „Can occupational labor shortages be identified using available data?«, Monthly Labor Review, 122 (3): 15-21.

Vinokur, Amiram D. i Schul, Yaacov (2002). »The Web of Coping Resources and Pathways to Reemployment Following a Job Loss«, Journal of Occupational Health Psychology, 7 (1): 68-83. doi:10.1037//1076-8998.7.1.68

Wallraff, Günter (1986 [1985]). Na samom dnu. Zagreb: Sveučilišna naklada Liber. Ward, Robin (1969). »A note on the testing of discrimination«, Race, 11 (2): 218-233. 
Warr, Peter (1994). »Age and employment«, u: Harry C. Triandis, Marvin D. Dunnette i Leaetta M. Hough (ur.). Handbook of Industrial and Organizational Psychology. Vol. 4. 2nd ed. Palo Alto, CA: Consulting Psychologists Press, str. 485-550.

Warr, Peter (2007). Work, Happiness, and Unhappiness. New York: Routledge.

\title{
Vojislav Trifunović or Tomislav Lučić: Who Will Be Easier to Hire in Zagreb? Testing Ethnic and Age Discrimination through the Method of Field Experiment
}

\author{
Darja MASLIĆ SERŠIĆ \\ Department of Psychology, Faculty of Humanities and Social Sciences, University \\ of Zagreb, Croatia \\ darja.maslic@ffzg.hr \\ Anton VUKELIĆ \\ Department of Sociology, Faculty of Humanities and Social Sciences, University \\ of Zagreb, Croatia \\ avukelic@ffzg.hr
}

Through conducting the field experiment or situation testing method, the authors checked the equality of opportunities of certain groups in the labour market. The writing test version of the paired-testing method was used to explore whether there is discrimination in the labour market in Zagreb against job applicants of Serbian nationality in comparison to their Croatian equivalent pair, and those of middle age in comparison to twenty year old persons. Besides, the authors were interested in whether the occurrence of discrimination is moderated by gender, education level and the current demand (occupational shortages) of a certain profile. Results are based on data collected from two samples of 173 job announcements published on the web portals "MojPosao", "Posao.hr" and in daily newspapers. The equivalent pairs of written applications were sent, applications were defined by the national identity or age of the candidates, and the outcome of those announcements was monitored. Related callbacks were dependant variables, categorized in three possible outcomes - a positive response (employer invited applicant to access the further selection process), a negative response or rejection, and finally, the absence of any feedback from the employer. The existence of discrimination based on nationality or age was confirmed in the first round of selection: a candidate with a Serbian sounding given name and surname had less chance of a positive outcome than the equivalent Croatian nationality candidate. The same goes for candidates in their forties in relation to those in their twenties. The level of education and general job availability for a certain occupation predict the outcome of applications by candidates in favoured groups, 
while the outcome for the discriminated groups is fully dependent on other factors that were not measured in this research. In addition to these findings, the paper deals with methodological issues and gives recommendations for future research.

Key words: discrimination, field experiment, paired-testing methodology, age, Croats, Serbs, employment 